\title{
Report of the Ad-hoc Review of the International Commission on Stratigraphy, September 2017
}

\author{
ARC Chair - IUGS Treasurer \\ https://doi.org/10.18814/epiiugs/2019/019031
}

In August 2017 the IUGS Executive Committee established an adhoc committee comprising Hiroshi Kitazato (Chair, IUGS Treasurer), Nigel Hughes (University of California at Riverside) and Paul Smith (Oxford Museum) and Edmund Nickless (Secretary, IUGS Councillor) to review the International Commission of Stratigraphy with the main goals of:

i. Analysing past performance (since the last review);

ii. Assessing the alignment of ICS objectives with the objectives and aims of IUGS;

iii. Identifying ways to increase the impact and significance of the Commission including concrete objectives for the near future.

We met at the Geological Society of London in London on 28/29 September 2017 and are grateful to the Society for hosting the meeting. On the first day we met with David Harper, Chair of ICS, to discuss with him background papers he had provided as listed in Annex A. Stan Finney, the immediate past Chair of ICS joined us by telephone briefly in the afternoon to clarify a number of matters relating to events during his tenure. The following day we drafted this report, which has been circulated to the review committee and agreed by them.

Overall, the Commission is in rude health, its outputs are remarkable and the voluntary contribution excellent. There is an unrivalled opportunity to promote the societal significance and relevance of the work of the Commission and how that highlights Earth history. GSSP and similar dedication ceremonies provide a platform to work with local media and scientific societies to bring the Commission's work before non-technical audiences. We recommend that this is done and in parallel there is a conversation with UNESCO to include the work of ICS (and IGGP) on display boards and other explanatory material in Geoparks.

We understand that the last review of ICS took place five to six years ago. It would have been useful to have had sight of that report to understand whether matters raised then persist and to benchmark progress. We recommend that the report of the immediately previous review is made available to future reviews; and that for openness, the reports of all reviews or at least a summary are published on the IUGS website.

Summarizing his first year as Chair, David Harper told us that it had not been without challenge. More than 350 individuals across many countries are involved in the work of the Commission. The annual allocation of $\$ 50 \mathrm{k}$, which has remained static for many years, funds the work of 16 subcommissions (principally essential GSSP-related field work) but is dependent on significant institutional support, gifts in kind and financial contributions from individuals involved. We estimate that the value of this support is probably in the order of a 20-fold addition to the funding from IUGS. We recommend that IUGS should do more to promote both the work of ICS as 'a jewel in the crown', and how the Commission acts as a family, builds trust and advances internationalism.

The Executive Committee comprises a Chair, Vice Chair and Secretary General. Two additional non-voting posts have recently been created - a Graphics Officer and an Informatics Officer who manages the Geodiversity Data Base. David told us that, as Chair, his workload was significantly more than he imagined when accepting the role. He thought that additional appointment/s to the Executive Committee might be necessary to share tasks within the Executive Committee more equitably and to take on new activities, such as raising external sponsorship. We support such appointments.

There is no post of Treasurer within the Executive Committee and consequently, David is directly involved in time consuming and complex arrangements to pay monies to the subcommissions. This is an unreasonable burden and distracts from more productive work. We recognise the existing heavy load on the IUGS Treasurer and Secretariat but recommend that steps are taken urgently to make payments centrally on the written authority of a nominated member of the ICS Executive Committee.

We are impressed by the high volume of excellent, fundamental science done by the Commission as a whole. In discussing the International Chronostratigraphical Chart, David saw it as part of a move towards a more integrated stratigraphic record sitting alongside other proxy records. Nevertheless, he accepted a need for a clear statement of direction now setting out a sharper focus, the need to complete stage definition and only then to undertake revisionary work. He told us that he intended to write to the Chairs of the subcommissions reporting briefly on his meeting with the Ad-hoc Review Committee. That could provide an opportunity to ask for views on future work and what success might look like. We encourage David to consult the subcommissions and recommend that basic studies are completed before beginning revisions. 
On matters of governance and the work of the subcommissions we were convinced that effective mechanisms are both in place and have been used to overcome inactivity (pre Cambrian) and bad behaviour (Triassic).

Regarding unacceptable behaviours, and gender/ethnic diversity within the membership of the subcommissions we think that there could be merit in a written Code of Conduct. Such codes are common to many scientific and professional societies and we recommend that thought is given to using them as a basis of a ICS-specific, published Code of Conduct. And to improve gender/ethnic diversity among the membership of the Commission as a whole, we recommend that consideration is given to issuing an Open Call for volunteers to serve on subcommissions.

The Chronostratigraphic Chart underpins much of the work of the resource-based industries and of the Timescale Foundation, yet it goes largely unacknowledged. We recognise the difficult history in the relationship of IUGS to the Timescale Foundation but nevertheless thought an approach could attract long-term external sponsorship. We recommend that plans are put in place as a matter of urgency to raise external sponsorship from these and other bodies, such as NSF, and that, if necessary, the President is actively involved in the dialogue with potential external funders.

We are pleased to learn about the development of the International Congress on Stratigraphy and links with specialist scientific societies including SEPM and IAB. The scope to work with more generalist scientific societies such as GSA and GSL by organising ICSrelated sessions at flagship meetings might be explored.

Only some of the output of ICS activities is published in Episodes recognising that authors should be free to publish elsewhere. Thought should be given to building a list of all published outputs on the Geodiversity database. Such a task could be made easier by providing subcommisions with a pro forma and style advice for reference citation in their annual reports.

We are grateful to David for his good humour and patience in answering our many questions.

13 October 2017 